\title{
Basal Defenses Induced in Pepper by Lipopolysaccharides Are Suppressed by Xanthomonas campestris pv. vesicatoria
}

\author{
Mansureh Keshavarzi, ${ }^{1,2}$ Soner Soylu, ${ }^{1,3}$ Ian Brown, ${ }^{1}$ Ulla Bonas, ${ }^{4}$ Michel Nicole,${ }^{5}$ John Rossiter, ${ }^{1}$ and \\ John Mansfield' \\ ${ }^{1}$ Department of Agricultural Sciences, Imperial College London, Wye Campus, Wye, Ashford, Kent TN25 5AH, U.K.; \\ ${ }^{2}$ Agricultural Research, Education and Extension Organisation (AREEO) of Islamic Republic of Iran, Tehran, Iran; \\ ${ }^{3}$ Department of Plant Protection, University of Mustafa Kemal, Faculty of Agriculture, 31034 Antakya, Hatay, Turkey; \\ ${ }^{4}$ Institute of Genetics, Martin-Luther-Universität Halle Wittenberg, D-06099 Halle (Saale), Germany; ${ }^{5}$ RD, UMR-DGPC, \\ Unité "Résistance des plantes", 911 Avenue Agropolis, B.P. 64501, 34394 Montpellier, France
}

Submitted 7 September 2003. Accepted 4 February 2004.

\begin{abstract}
The nonpathogenic hrcC mutant of Xanthomonas campestris pv. vesicatoria 85-10::hrpA22 multiplied in pepper leaves if it was mixed with pathogenic strains of $X$. campestris pv. vesicatoria. Reactions to the mutant alone included localized deposition of phenolics and callose in papillae, and alterations to the plant cell wall leading to increased electron density. Electron microscopy showed that the localized responses were suppressed in the presence of wildtype bacteria but other wall changes occurred at some sites, involving cellulose-rich ingrowth of the wall. Multiplication of the $h r p$ mutant in mixed inocula was confirmed by tagging 85-10::hrpA22 using immunocytochemical location of AvrBs3 expressed from the plasmid pD36. Elicitors of callose deposition and other wall changes were isolated from the $h r c C$ mutant. Activity in extracts of bacteria was attributed to the presence of high molecular weight lipopolysaccharides (LPS). Wildtype $X$. campestris pv. vesicatoria suppressed induction of structural changes caused by purified LPS. Results obtained suggest that effector proteins produced by phytopathogenic bacteria and delivered by the type III secretion system may have a key role in suppressing the basal defense responses activated by bacterial LPS, which lead to restricted multiplication of nonpathogens such as hrp mutants.
\end{abstract}

The type III secretion system (TTSS) has an essential role in the pathogenicity of gram-negative bacteria to animals and plants. The TTSS is designed to deliver bacterial effector proteins into cells of potential hosts (Cornelis 2002; Cornelis and van Gijsegem 2000). The role of effector proteins in the bacterial colonization of plants is not clearly understood, but it has been proposed that an essential function is to suppress host defenses (Büttner and Bonas 2003). In Xanthomonas spp., as in other plant pathogens, genes encoding the secretion apparatus are clustered into the hrp pathogenicity island. Some $h r p$ genes encode proteins that are conserved among plant and animal pathogens and, therefore, have been designated hrp-conserved ( $h r c$ ) genes. An example of such a gene is $h r c C$ of $X$. campestris pv. vesicatoria, which encodes the core outer membrane se-

Corresponding author: J. Mansfield; Telephone: 44 (0)2075942764; Fax: 44 (0)2075942640; E-mail: j.Mansfield@imperial.ac.uk cretin component of the TTSS (Cornelis and van Gijsegem 2000). Note that $h r c C$ in $X$. campestris pv. vesicatoria originally was designated $h r p A$ (Bonas et al. 1991).

The hrp mutant phenotype in phytopathogenic bacteria is characterized by the lack of a macroscopically visible response in plants susceptible or resistant to the original wildtype strain, and failure of the mutant to multiply in the plant (Lindgren 1997). Neither disease nor the hypersensitive reaction (HR) are caused by hrp mutants. It is clear, however, that plants activate defense responses to restrict the multiplication of nonpathogenic bacteria. For example, Jakobek and Lindgren (1993) found that several defense-associated transcripts accumulated in bean following challenge by an hrp mutant of Pseudomonas syringae pv. tabaci and also following challenge with the nonpathogen Escherichia coli. Recent analysis of transcripts induced in Arabidopsis spp. by an $h r p A$ (pilin) mutant of $P$. syringae pv. tomato revealed rapid induction of a number of genes, indicating the existence of a basal recognition mechanism allowing detection of any invading microbe (de Torres et al. 2003). Microscopical studies of interactions between hrp mutants of $P$. syringae pv. phaseolicola and $X$. campestris pv. vesicatoria and a range of plants have revealed highly localized alterations occurring in plant cells adjacent to the compromised bacteria (Bestwick et al. 1995, 1998; Brown et al. 1995, 1998). Changes to the plant cell wall in contact with hrp mutants included incorporation of phenolics and hydroxyproline- and proline-rich glycoproteins (HRGPs and PRPs, respectively) which, in lettuce and French bean, were associated with the presence of $\mathrm{H}_{2} \mathrm{O}_{2}$ and peroxidase activity at reaction sites. An additional response observed in all plants examined, including bean, lettuce, pepper, Arabidopsis spp., and tobacco, is the deposition of papillae comprised mainly of callose ( $\beta, 1-3$ glucan) on the inner face of the altered plant cell wall (Bestwick et al. 1998; Hauck et al. 2003).

hrp mutants and saprophytic bacteria fail to multiply within the intercellular spaces of leaves, but the mechanism of restriction of bacterial colonization is not known. Several antimicrobial factors have been suggested to have a role in generating a hostile microenvironment; namely, the localized production of $\mathrm{H}_{2} \mathrm{O}_{2}$, toxic phenolic free radicals, and agglutination by crosslinking proteins (e.g., HRGPs). The hrp mutant bacteria often appear grossly distorted in electron micrographs, taking up angular forms indicative of colony desiccation (Bestwick et 
al. 1998). Therefore, it has been proposed that a primary factor causing restricted bacterial multiplication may be the lack of water reaching bacterial cells through the normal water-conducting route of the cellulosic plant cell wall. The rapid and localized changes to the wall may generate hydrophobic conditions, which prevent water flow to reaction sites (Bestwick et al. 1998; Innes 2001).

Brown and associates (1995), in their study of $X$. campestris pv. vesicatoria, proposed that wild-type bacteria are able to suppress the cell wall alterations that constitute a basal form of resistance to bacterial colonization. They also demonstrated that papillae and wall alterations occurred in response to challenge by dead bacteria, although elicitors of the plant's basic resistance were not characterized. Here we describe experiments extending our analysis of the $X$. campestris pv. vesicatoriapepper model system to examine responses to hrp mutants. Reactions occurring in cultivars resistant and susceptible to the wild-type strains were compared. The localized changes occurring in pepper were defined by histochemistry, suppressive effects were examined using mixtures of wild-type and "tagged" hrp mutants, and, finally, high molecular weight lipopolysaccharides (LPS) were identified as important elicitors of the plant's basal resistance response.

\section{RESULTS}

\section{Characterization of localized reactions to bacterial challenge.}

Quantitative data on the frequency of occurrence and size of papillae produced in pepper cvs. ECW-10R and ECW-30R challenged with $X$. campestris pv. vesicatoria strains 71-21, 85-10, and the hrp mutant 85-10::hrp A22 are summarized in Table 1, which extends our earlier data (Brown et al. 1995).
The resistance of ECW-10R and ECW-30R to wild-type $X$. campestris pv. vesicatoria is expressed by the HR, which is visualized by tissue collapse within 10 and $30 \mathrm{~h}$ after inoculation, respectively (Minsavage et al. 1980). Large papillae were observed only in response to the hrp mutant. Some reaction sites developed papillae during compatible and incompatible (HR) interactions to wild-type bacteria but the deposits were small and, like the plant cell walls, lacked the electron density associated with alterations occurring in response to the hrp mutant. The clear qualitative difference between deposits is shown in Figure 1A and B.

Immunogold labeling of callose and histochemical detection of cellulose revealed the accumulation of both polysaccharides at reaction sites. Callose appeared to be a major component of

Table 1. Percentage of sites with papillae in categories 1 to $3,24 \mathrm{~h}$ after inoculation $^{\mathrm{a}}$

\begin{tabular}{lccrr}
\hline Cultivar, strain $^{\mathbf{b}}$ & $\begin{array}{c}\text { No papilla } \\
\text { formed }\end{array}$ & $\mathbf{1}$ & $\mathbf{2}$ & $\mathbf{3}$ \\
\hline ECW-30R & & & & \\
$85-10(\mathrm{~S})$ & 61 & 38 & 1 & 0 \\
71-21 (slow HR) & 75 & 22 & 3 & 0 \\
85-10 hrpA22 $_{\text {ECW-10R }}^{\mathrm{c}}$ & 16 & 45 & 20 & 19 \\
$71-21$ (S) & 55 & 39 & 6 & 0 \\
$85-10$ hrpA22 $^{-17}$ & 17 & 55 & 16 & 12 \\
\hline
\end{tabular}

${ }^{a}$ Single sections of at least 30 sites were examined for each strain. Categories were based on the size and electron density of papillae: $1=$ small apposition less than $0.25 \mu \mathrm{m}$ thick; $2=$ as 1 but 0.25 to $0.75 \mu \mathrm{m}$ thick; $3=$ deposit at least $0.75 \mu \mathrm{m}$ thick with some osmiophilic inclusions.

${ }^{\mathrm{b}} \mathrm{S}=$ susceptible response, $\mathrm{HR}=$ hypersensitive reaction.

${ }^{c}$ Note that strain 85-10 caused a rapid HR in pepper cv. ECW-10R, with cell collapse occurring before $24 \mathrm{~h}$ and no significant papilla deposition.
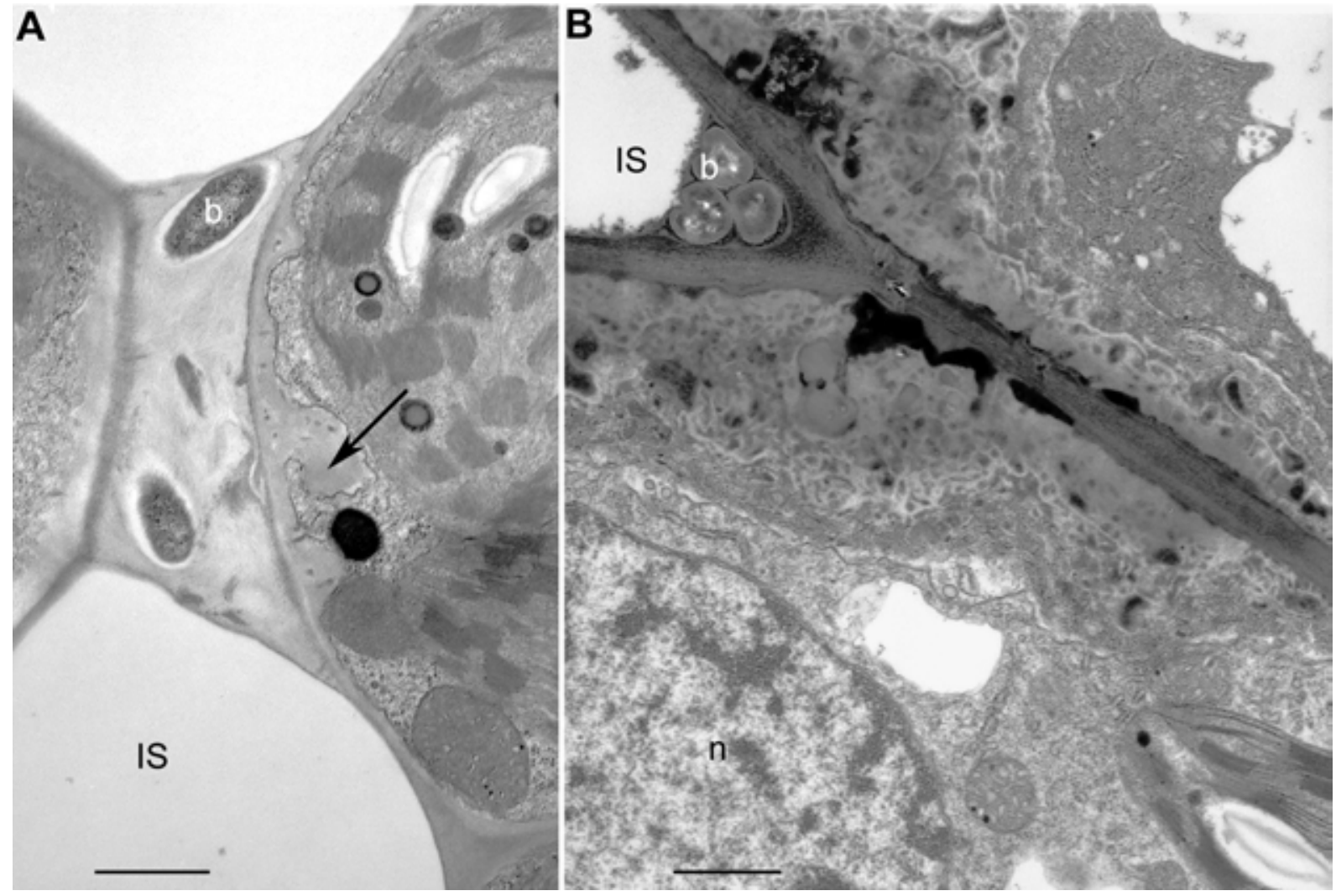

Fig. 1. Comparison of papillae formed $48 \mathrm{~h}$ after inoculation in pepper cv. ECW-30R in response to A, Xanthomonas campestris pv. vesicatoria wild-type strain 85-10 or the hrp mutant 85-10::hrpA22. Note the absence of osmiophilic or electron-dense material from the deposit formed in response to the wildtype strain (arrow). Bars: $A=1 \mu \mathrm{m}$ and $\mathrm{B}=0.5 \mu \mathrm{m}$; IS, intercellular space; $\mathrm{b}$, bacterium, $\mathrm{n}$, nucleus. 
papillae induced by the hrp mutant but was much less evident next to wild-type bacteria, being absent from many sites (Fig. $2 \mathrm{~A}$ and $\mathrm{B})$. By contrast, localized cellulose deposition was more apparent next to wild-type bacteria (compare Fig. 2C and D). The plant cell wall per se stained only for cellulose, not callose, which invariably was located on the cytoplasmic face of the plant cell wall.
Deposition of callose next to the hrp mutant was also revealed by fluorescence microscopy after aniline blue staining. Sites responding to the hrp mutant also developed strong autofluorescence and stained green blue with toluidine blue (Fig. 3), indicating local accumulation of phenolics (O'Brien and McCully 1981). Similarly localized staining of plant cell walls was not observed following inoculation with wild-type bacteria;

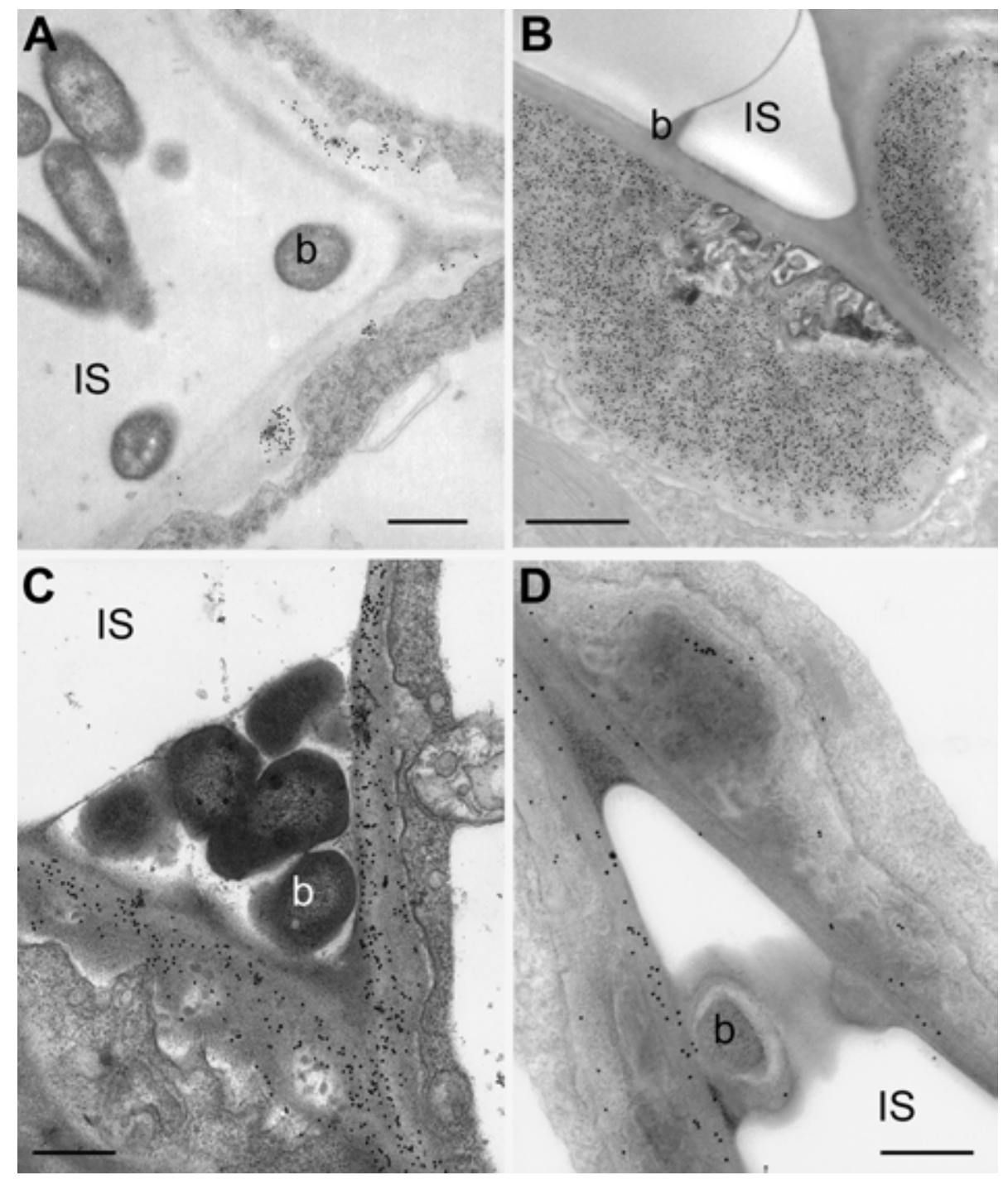

Fig. 2. Cytochemical localization (with gold particles) of $\mathbf{A}$ and $\mathbf{B}$, callose and $\mathbf{C}$ and $\mathbf{D}$, cellulose in mesophyll cells next to $\mathbf{A}$ and $\mathbf{C}$, Xanthomonas campestris pv. vesicatoria wild-type 85-10 and $\mathbf{B}$ and $\mathbf{D}, 85-10::$ hrpA22 in cv. ECW-30R, $48 \mathrm{~h}$ after inoculation. Bars: $\mathrm{A}$ and $\mathrm{B}=0.5 \mu \mathrm{m} ; \mathrm{C}$ and $\mathrm{D}=0.25$ $\mu \mathrm{m} ; \mathrm{IS}$, intercellular space; b, bacterium.

Table 2. Bacterial multiplication in leaves of pepper cv. ECW-30R

\begin{tabular}{|c|c|c|c|c|c|}
\hline \multirow[b]{2}{*}{ Procedure } & \multirow[b]{2}{*}{ Bacterial strains ${ }^{\mathrm{b}}$} & \multicolumn{4}{|c|}{ 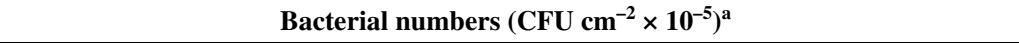 } \\
\hline & & $\mathbf{0 h}$ & $24 \mathrm{~h}$ & $48 \mathrm{~h}$ & $72 \mathrm{~h}$ \\
\hline \multirow[t]{2}{*}{ Single inocula } & 85-10::hrpA22 & $112 \pm 9.2$ & $81 \pm 12.3$ & $98 \pm 7.8$ & $95 \pm 13.6$ \\
\hline & $85-10$ & $15 \pm 1.4$ & $270 \pm 3.8$ & $4,500 \pm 189$ & $7,140 \pm 267$ \\
\hline \multirow[t]{2}{*}{ Mixed inoculation $^{\mathrm{c}}$} & 85-10::hrpA22 & $85 \pm 1$ & $387 \pm 32$ & $4,530 \pm 610$ & $6,820 \pm 1180$ \\
\hline & $85-10$ & $22 \pm 2.3$ & $293 \pm 46$ & $3,230 \pm 720$ & $3,400 \pm 457$ \\
\hline \multirow[t]{2}{*}{ Sequential inoculation $^{\mathrm{d}}$} & 85-10::hrpA22 & $95 \pm 8.6$ & $74 \pm 2.5$ & $254 \pm 16.7$ & $1,070 \pm 246$ \\
\hline & $85-10$ & $11 \pm 2$ & $8 \pm 1$ & $75 \pm 34$ & $458 \pm 130$ \\
\hline
\end{tabular}

${ }^{a}$ Values represent the mean \pm standard error of the mean from three 0.5 -cm-diameter leaf disks.

${ }^{\mathrm{b}}$ In all interactions, concentration of the Xanthomonas campestris pv. vesicatoria wild-type and the hrp mutant inoculated were $1 \times 10^{8}$ and $5 \times 10^{8}$ cells $\mathrm{ml}^{-1}$, respectively.

${ }^{\mathrm{c}}$ Co-inoculation of wild-type 85-10 and hrp mutant 85-10::hrpA22 strains.

${ }^{\mathrm{d}}$ Pretreatment with $h r p$ mutant strain $85-10:$ : $r p A 22$ 48h before challenge with wild-type strain $85-10$; the data in this procedure are given after challenge with wild-type bacteria (i.e., $24 \mathrm{~h}$ means $24 \mathrm{~h}$ after challenge with wild-type, which is 3 days after inoculation of the $h r p$ mutant). 
however, cells undergoing the HR in pepper ECW-30R or ECW-10R did stain with toluidine blue (data not shown).

\section{Effect of wild-type bacteria on hrp mutants.}

Bacterial multiplication. The possibility that the basal defense against Hrp mutants was suppressed by wild-type bacteria was investigated using mixed inocula and sequential inoculation. In the absence of wild-type 85-10, the 85-10:: hrpA22 mutant failed to multiply within 3 days after inoculation. By contrast, growth of 85-10::hrpA22 from mixed inocula was as rapid as the wild-type strain (Table 2). Sequential inoculation with 85-10 $48 \mathrm{~h}$ after challenge with the hrp mutant also seemed to "rescue" the mutant bacteria, promoting their growth despite a general reduction in multiplication of the wild-type strain, as recorded in Table 2.
Cellular reactions. A series of mixed inocula, consisting of hrp mutant and pathogenic strains, either $X$. campestris pv. vesicatoria $85-10$ or the extracellular polysaccharide negative $\left(\mathrm{EPS}^{-}\right.$) mutant 85-10::454, were prepared. The EPS ${ }^{-}$mutant was used in an attempt to differentiate colonies in planta because the reduced formation of EPS causes bacteria to be packed closely together (Brown et al. 1995). In all inocula, the final concentration of the hrp mutant bacteria cells was 5 $\times 10^{8} \mathrm{ml}^{-1}$ but the wild-type or EPS ${ }^{-}$bacterial cell concentration varied at $5 \times 10^{6}, 5 \times 10^{7}, 1 \times 10^{8}$, and $5 \times 10^{8} \mathrm{ml}^{-1}$. In this way, the effect of the proportion of wild-type cells within the mixed inocula on the activation of local defense responses was examined. Preliminary observations on the tissues indicated that, regardless of the final concentration of the pathogenic strain in the mixed inocula, local plant cell
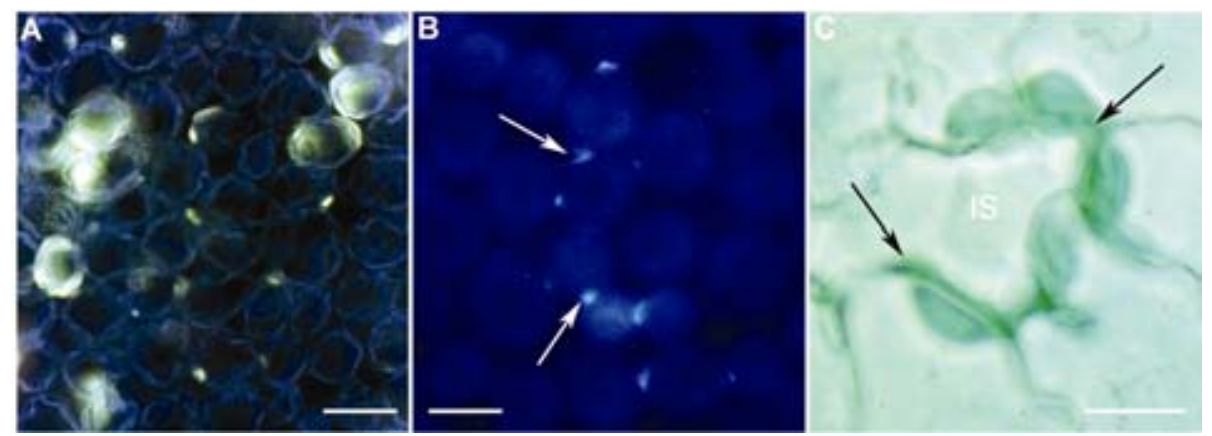

Fig. 3. Histochemical localization of callose and phenolics in leaves of pepper ECW-30R $48 \mathrm{~h}$ after inoculation with $85-10 \%$ : hrpA22. A, Pale yellow fluorescence of callose deposits after staining with aniline blue. B, Autofluorescence of unstained reaction sites (arrowed), UV excitation (340 to $380 \mathrm{~nm}$ ). $\mathbf{C}$, Blue or green staining of papillae and altered walls (arrowed) after treatment with toluidine blue indicating phenolic accumulation. Bars: A, B, and C = 20,50 ,and $100 \mu \mathrm{m}$ respectively; IS, intercellular space..

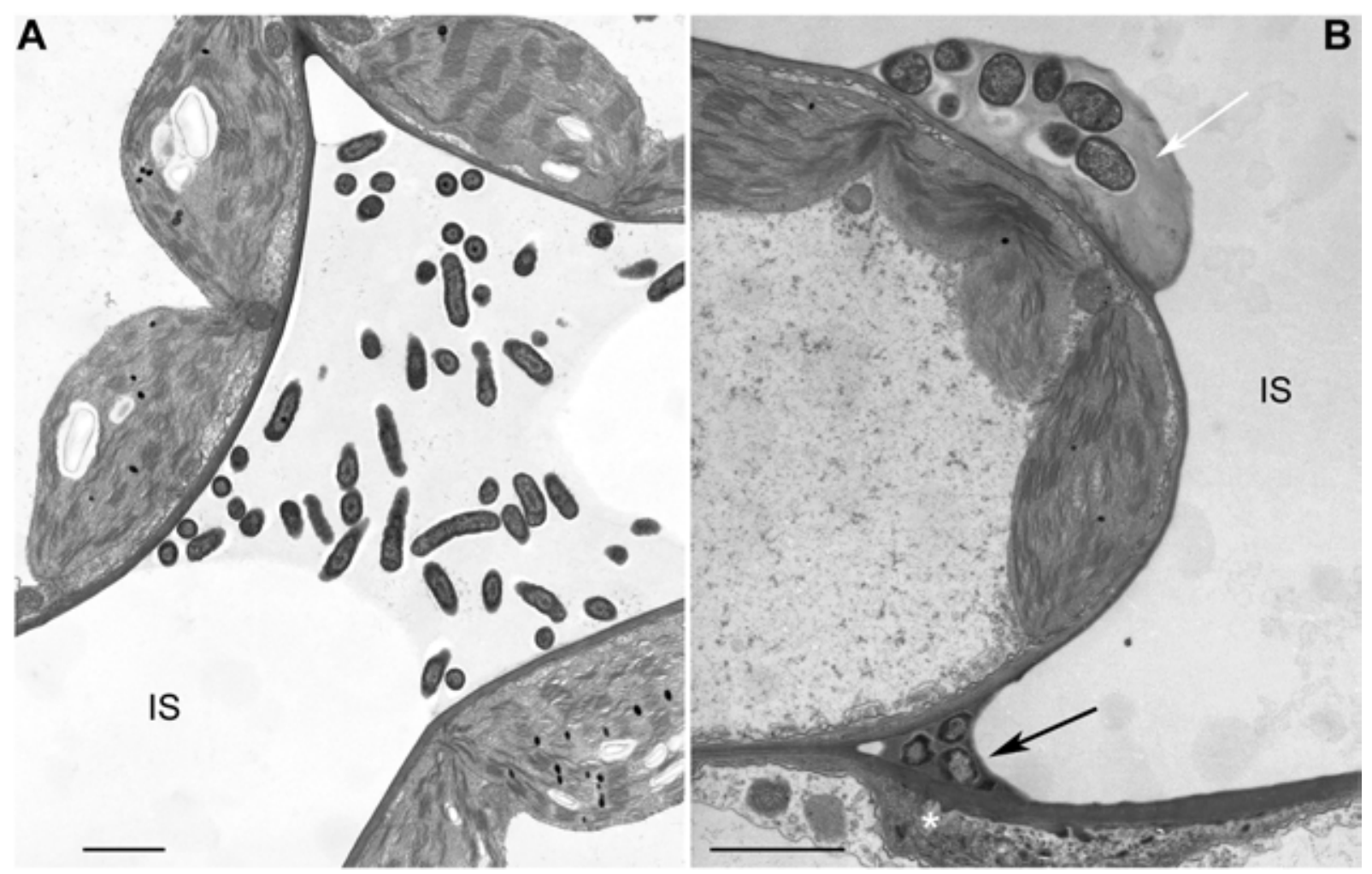

Fig. 4. Bacterial colony development and plant responses to mixed inocula of the pathogenic extracellular polysaccharide (EPS) mutant 85-10::454 and the hrp mutant 85-10::hrpA22, $48 \mathrm{~h}$ after inoculation of ECW-30R. A, A large bacterial colony has developed containing fibrillar EPS; no plant cell wall changes are apparent. B, An agglutinated bacterial colony (black arrow) is attached at the junction between two mesophyll cells. In one cell, a large papilla has been deposited (asterisk); whereas, in the adjacent cell, which also has a colony with wild-type morphology attached (white arrow), local defenses are not activated. Bars $=2 \mu \mathrm{m}$; IS, intercellular space; $b$, bacterium. 
defenses typically were absent from interaction sites and almost all of the bacteria grew freely within the intercellular spaces (Fig. 4).

An interesting feature of the mixed inoculations was the appearance of EPS surrounding bacterial colonies consisting of hrp mutant and EPS ${ }^{-}$strains. When inoculated alone, the EPS $^{-}$bacteria were packed closely together (Brown et al. 1995); however, in mixed colonies, the accumulation of fibrillar EPS was as observed with fully wild-type strains (Fig. 4). The EPS observed within colonies, therefore, was produced by the hrp mutant. This observation clearly demonstrated the normal multiplication and metabolic activities of hrp mutant bacteria in planta when they were mixed with a pathogenic strain.

The presence of nonpathogenic hrp mutants within rapidly expanding colonies containing pathogenic bacteria was confirmed using immunogold labeling to "tag" the hrp mutant. To increase the resolution of immunocytochemical methods, in addition to using double fixation procedures, the tissues were single-fixed and embedded in LR-white resin. The transconjugant 85-10::hrpA22(pD36), which expresses avrBs3 from a strong vector promoter, was used instead of 85$10:$ hrpA22 and the anti-AvrBs3 antibody applied to locate AvrBs3 and, thereby, to tag the Hrp mutant. In addition, the callose immunolabeling procedure was used to define the type of papilla formed next to bacterial colonies. The efficiency of the anti-AvrBs3 antibody was first confirmed in the control leaves inoculated with the hrp mutant or wild-type bacteria alone. None of the wild-type cells was labeled with the anti-AvrBs3 antibody, whereas the label was detected in the cytoplasm of hrp mutant bacteria expressing avrBs3. Using mixed inocula (Fig. 5) and consistent with the bacterial population data, the Hrp mutant bacteria multiplied freely in the mixed colonies. The anti- $\beta, 1-3$ glucan antibody revealed the deposition of, at most, very low levels of callose adjacent to the mixed colonies, whereas the hrp mutant bacteria alone typically had triggered callose-rich papillae (Fig. 5). Using immunocytochemical methods to localize AvrBs3 protein inside the hrp mutant bacteria, the inclusion of the mutants within colonies of wild-type bacteria and their multiplication was confirmed. Despite the presence of AvrBs3 within the hrp mutant, the HR was not induced in ECW-30R. The mutation in $h r c C$ clearly prevented delivery of the AvrBs3 protein despite rapid multiplication of the mutant in mixed inocula.

Agglutinated colonies occasionally were observed if inocula contained a low proportion of virulent bacteria. Where restricted colonies occurred at cell junctions, they usually had induced

Table 3. Activities of sonicated suspension and soluble elicitors prepared from Xanthomonas campestris pv. vesicatoria strain 85-10::hrpA22 standardized to the initial concentration of suspension, $10^{9}$ bacteria ml $\mathrm{ml}^{-1}$

\begin{tabular}{ll}
\hline Elicitor & End-point $^{\mathrm{a}}$ \\
\hline Sonicated suspension & \\
Soluble elicitor & $1 / 64$ \\
Insoluble elicitor & $1 / 64$ \\
Soluble elicitor & $1 / 32$ \\
$>100 \mathrm{kDa}$ & \\
$<100 \mathrm{kDa}$ & $1 / 64$ \\
Soluble elicitor, heat treated & $\ldots$ \\
Supernatant & $1 / 64$ \\
Pellet & $1 / 64$ \\
$>100 \mathrm{kDa}$ & $1 / 64$ \\
$<100 \mathrm{kDa}$ & $1 / 16$ \\
Soluble elicitor, freeze-thawed & $1 / 64$ \\
$>100 \mathrm{kDa}$ & $1 / 64$ \\
$<100 \mathrm{kDa}$ & $1 / 64$ \\
Soluble elicitor treated with proteases & $\ldots$ \\
\hline
\end{tabular}

${ }^{\mathrm{a}}$ End point of activity was determined by injection of doubling dilutions of elicitor preparations into leaf tissues; ... indicates no activity before dilution. Concentrations were adjusted to correspond to the original volume of bacterial suspension at $10^{9}$ cells $\mathrm{ml}^{-1}$. Data are summarized from repeated experiments.

${ }^{\mathrm{b}}$ Boiled suspension gave the same end point.

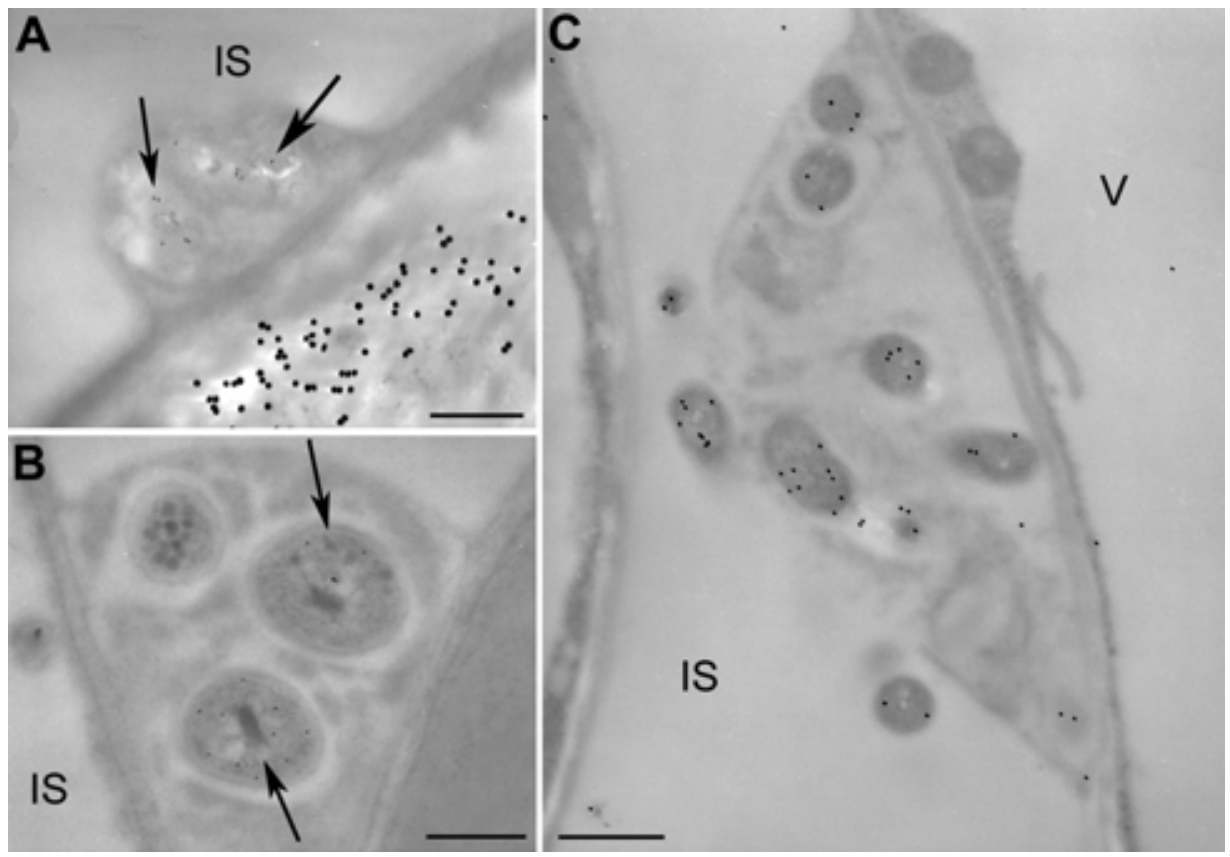

Fig. 5. Tagging hrp mutant bacteria by immunocytochemical localization of AvrBs3 (produced from pD36) in leaves of pepper cv. ECW-30R. A, Detection of AvrBs3 (small gold label, arrowed in Xanthomonas campestris pv. vesicatoria) and callose (large gold label) adjacent to the plant cell wall $24 \mathrm{~h}$ after inoculation with 85-10::hrpA22 (pD36) alone. B, Detection of AvrBs3 (gold label arrowed) in 85-10::hrpA22 (pD36) within mixed inoculum with pathogenic, but extracellular polysaccharide negative strain 85-10::454. The section also was immunogold labeled for callose detection (as in A), but no callose-rich papilla developed next to the mixed colony $48 \mathrm{~h}$ after inoculation. C, Tagging with anti-AvrBs3 antibody detects 85-10::hrpA22 (pD36) within a large colony formed $48 \mathrm{~h}$ after inoculation with a mixture of the $h r p$ mutant and wild-type strain $85-10$. Bars: A and B $=0.2 \mu \mathrm{m}, \mathrm{C}=1 \mu \mathrm{m}$; IS, intercellular space; v, plant cell vacuole. 
responses such as papillae in both adjacent cells (Fig. 1). However, with mixed inocula, if one plant cell was also adjacent to a rapidly expanding colony, no response was observed to the nonpathogenic bacteria. The apparent suppression of responses within plant cells is illustrated in Figure 4B.

\section{Identification of elicitors of papilla deposition.}

Our results showed that hrp mutants elicited striking alterations to plant cell walls and the deposition of papillae containing large amounts of callose. The localized response was suppressed by wild-type bacteria, whose presence allowed the hrp mutant to multiply. The production of localized wall alterations and papilla deposition by hrp mutants occurs without a functional TTSS. Earlier experiments by Brown and associates (1995) had demonstrated that papillae were induced by pathogenic bacteria heat-killed by microwave treatment. Elicitors were now characterized further based on their ability to induce accumulation of callose, which was detected by aniline blue fluorescence staining (Fig. 3). In addition to callose induction, active fractions also caused slight yellowing of infiltration sites 4 days after inoculation. The end point of activity was defined as the lowest dilution of cell fractions that caused a detectable response (both callose deposition and yellowing) by 5 days after inoculation.
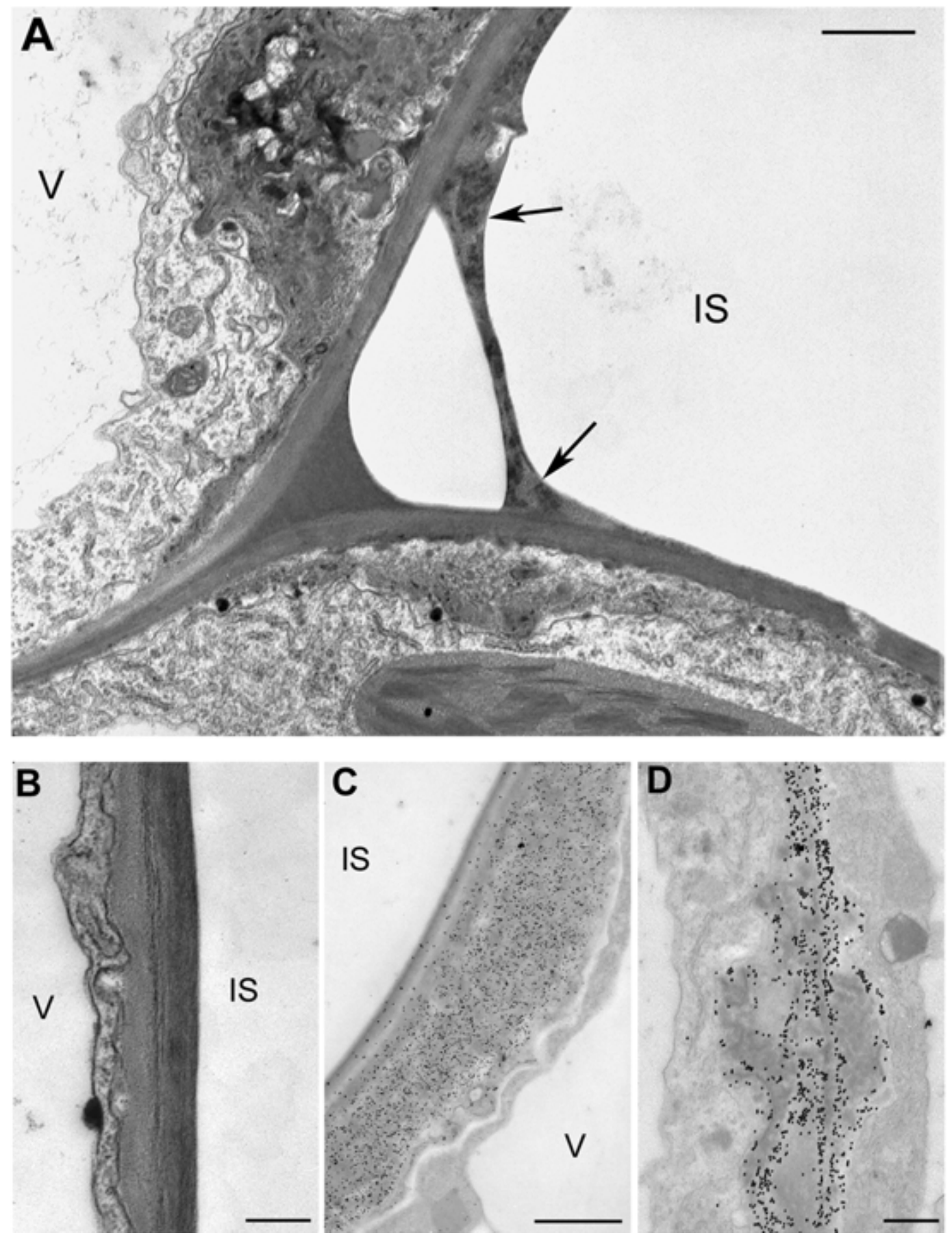

Fig. 6. Responses of pepper mesophyll cells to lipopolysaccharides (LPS) $\left(100 \mu \mathrm{g} \mathrm{ml}{ }^{-1}\right)$ prepared from Xanthomonas campestris pv. vesicatoria 85$10::$ rrpA22, $48 \mathrm{~h}$ after infiltration. A, Increased electron density in cell walls and papilla formation adjacent to an aggregate of LPS (arrowed) at a cell junction. B, Deposition of layers of material along the inner face of the mesophyll cell wall. C, Immunogold localization of callose within a large papilla using antibodies to $\beta, 1-3$ glucan. D, Histochemical detection of cellulose (gold label) within deposits along plant cell walls. $\mathrm{Bars}$ : $\mathrm{A}$ and $\mathrm{D}=1 \mu \mathrm{m}, \mathrm{B}=0.2$ $\mu \mathrm{m}, \mathrm{C}=0.5 \mu \mathrm{m} ; \mathrm{IS}$, intercellular space; $\mathrm{v}$, plant cell vacuole. 
Recovery of soluble elicitor from sonicated cells. Suspensions of boiled or sonicated 85-10::hrpA22 cells actively induced papilla deposition. The simple fractionation scheme followed (Table 3 ) showed that activity from sonicated cells was retained in the cell-free supernatant after centrifugation. The solubilized elicitor was $>100 \mathrm{kDa}$ in mass, insensitive to boiling or freezing and thawing, and only slightly affected by treatment with proteases (Table 3). Electron microscopy confirmed that the elicitor solubilized by sonication induced all components of the localized papilla response and also a more general deposition of a layer of callose and cellulose inside the plant cell wall (data not shown).

Identification and activity of LPS. The origin of the elicitor was examined by testing the activity of outer membrane preparations that were recovered from intact bacterial cells by treatment with 1\% EDTA (Hodson et al. 1995). Outer membrane extracts elicited strong yellowing and papilla deposition. The active elicitor had a molecular weight (MW) over $100 \mathrm{KDa}$ (as assessed by ultrafiltration). The active principle within the outer membrane survived boiling, freezing and thawing, and treatment with proteases or nucleases. Treatment of the EDTA extract with aqueous hot phenol generated three distinct layers: an upper aqueous phase, a lower phenol-rich layer, and an insoluble residue at the phenol-water interface. Elicitor activity was found only in the water phase.

The fractionation and outer membrane isolation experiments pointed to components of LPS as the active elicitor in hrp mutant bacteria. Therefore, LPS was purified from $X$. campestris pv. vesicatoria 85-10::hrpA22, essentially using the aqueous hot phenol method described by Westphal and Jann (1965). Preparations of LPS recovered after treatment with DNase, RNase, and protease elicited papillae and alterations to the plant cell wall, including deposition of callose and, to a lesser extent, cellulose (Fig. 6). Pretreatment of pepper ECW-30R with LPS $48 \mathrm{~h}$ prior to bacterial inoculation reduced subsequent symptom development caused by the wild-type $X$. campestris pv. vesicatoria strain 85-10 in a concentrationdependent manner (Table 4). Electron microscopy studies showed that, in tissue protected by LPS pretreatment, bacteria failed to multiply but did not induce striking papilla deposits other than those produced in response to LPS alone (Fig. 6). If wild-type bacteria were inoculated prior to or at the same time as treatment with LPS, bacterial multiplication and symptom development typically were not affected. Using mixed inoculation treatments, no major cell wall alterations were observed in cells adjacent to bacteria, other than those typically found next to colonies of virulent $X$. campestris pv. vesicatoria (Fig. 1A).

Further fractionation of LPS was performed by size exclusion chromatography on a Sepharose 2B column eluted with either $50 \mathrm{mM}$ imidazole (pH 7.0) or $100 \mathrm{mM}$ triethylamine (TEA) and $10 \mathrm{mM}$ EDTA ( $\mathrm{pH}$ 7.0). Using imidazole, elicitor activity was observed in the excluded as well as included material, which all contained carbohydrate and 2-keto-3-deoxyoctonate (KDO) (Fig. 7A). Elution with EDTA-TEA resolved a broad peak of KDO-rich material that induced papilla deposition. By contrast, carbohydrate-rich fractions of lower MW were inactive (Fig. 7B). Electrophoresis followed by silver staining of EDTA (outer membrane) and LPS preparations revealed the characteristic ladder-like banding pattern of LPS. The banding patterns observed in active fractions of LPS recovered from the Sepharose 2B column eluted with EDTA-TEA are illustrated in Figure 8. Similar polyacrylamide gel electrophoresis (PAGE) gels were obtained with LPS purified from $X$. campestris pv. vesicatoria wild-type strain 85-10 (data not shown).

\section{DISCUSSION}

The failure of hrp mutant bacteria to multiply in the intercellular spaces of pepper was associated with characteristic changes to adjacent plant cell walls, including incorporation of phenolics and deposition of callose-rich papillae. The minor changes to the plant cell wall occurring during challenge by pathogenic strains (whether avirulent or virulent) were qualitatively different and, in particular, deposited material contained less callose but more cellulose. Increased electron density in the cell wall was observed only after inoculation with the hrp mutant. Plant cell wall alterations have been recognized as forms of basal resistance to fungi as well as to bacteria. The altered cell wall often has been considered as a physical barrier to penetration by fungal hyphae (Heath 2000; Mellersh et al. 2002). In some cases, the papilla ensheaths the invading hyphae that do not manage to breach the altered plant cell wall (O'Connell et al. 1990). Following bacterial challenge, such as that presented by xanthomonad and pseudomonad leaf spot pathogens, plant cell wall alterations may act as a barrier to transfer of nutrients and water.

Table 4. Development of disease symptoms in leaves of pepper cv. ECW-30R following treatment with combinations of lipopolysaccharides (LPS) and Xanthomonas campestris pv. vesicatoria wild-type strain 85-10

\begin{tabular}{|c|c|c|c|c|c|c|}
\hline \multirow[b]{2}{*}{ Treatment } & \multirow[b]{2}{*}{ Bacteria $\mathbf{m l}^{-1}$} & \multirow[b]{2}{*}{ LPS $\mu \mathrm{g} \mathrm{ml}^{-1}$} & \multicolumn{4}{|c|}{ Symptom appearance, days after infiltration ${ }^{\mathrm{a}}$} \\
\hline & & & 3 & 4 & 8 & 12 \\
\hline \multicolumn{7}{|l|}{ Controls $\mathrm{b}^{\mathrm{b}}$} \\
\hline \multirow[t]{3}{*}{ Wild-type } & $1 \times 10^{7}$ & $\ldots$ & + & +++ & ++++ & \\
\hline & $5 \times 10^{7}$ & $\ldots$ & ++ & ++++ & & \\
\hline & $1 \times 10^{8}$ & $\ldots$ & ++++ & & & \\
\hline \multirow{6}{*}{$\begin{array}{l}\text { Sequential inoculations } \\
\text { LPS prior to wild-type }^{c}\end{array}$} & & & & & & \\
\hline & $1 \times 10^{7}$ & 10 to 40 & $\ldots$ & $\ldots$ & $\ldots$ & ++++ \\
\hline & & 60 to 980 & $\ldots$ & $\ldots$ & $\ldots$ & \\
\hline & $1 \times 10^{8}$ & 10 to 40 & $\ldots$ & ++++ & & \\
\hline & & 60 to 80 & $\ldots$ & $\ldots$ & ++++ & \\
\hline & & 100 to 980 & $\ldots$ & $\ldots$ & $\ldots$ & ++++ \\
\hline \multirow[t]{2}{*}{ Wild-type prior to LPS ${ }^{\mathrm{d}}$} & $1 \times 10^{7}$ & 100 & + & +++ & ++++ & \\
\hline & $1 \times 10^{8}$ & 100 & ++++ & & & \\
\hline \multicolumn{7}{|l|}{ Co-inoculation ${ }^{\mathrm{e}}$} \\
\hline LPS + wild-type & $5 \times 10^{7}$ & 100 & ++ & ++++ & & \\
\hline
\end{tabular}


In order to multiply within the intercellular spaces, phytopathogenic bacteria must be able to access the flow of assimilate through the plant cell wall. In contrast to reactions to hrp mutants, the cellulose-rich alterations occasionally observed in response to pathogenic $X$. campestris pv. vesicatoria are morphologically very similar to the adaptations of the cell wall observed in phloem transfer cells that are thought to facilitate nutrient exchange during loading and unloading of the plant's transport system (Brentwood and Cronshaw 1978; Pate and Gunning 1972). Pathogenic strains of X. campestris pv. vesicatoria, therefore, may cause beneficial local modifications to the plant cell wall that are designed to improve access to nutrients and water.

Experiments with mixed inocula demonstrated the suppressive effect of $X$. campestris pv. vesicatoria wild-type strains on hrp mutant-induced cell wall alterations. Suppression of basal resistance would appear to function throughout the affected cell (Fig. 4). Expression of AvrBs3 allowed the hrp mutants to be tagged and confirmed their presence in expanding colonies. Despite the accumulation of AvrBs3,
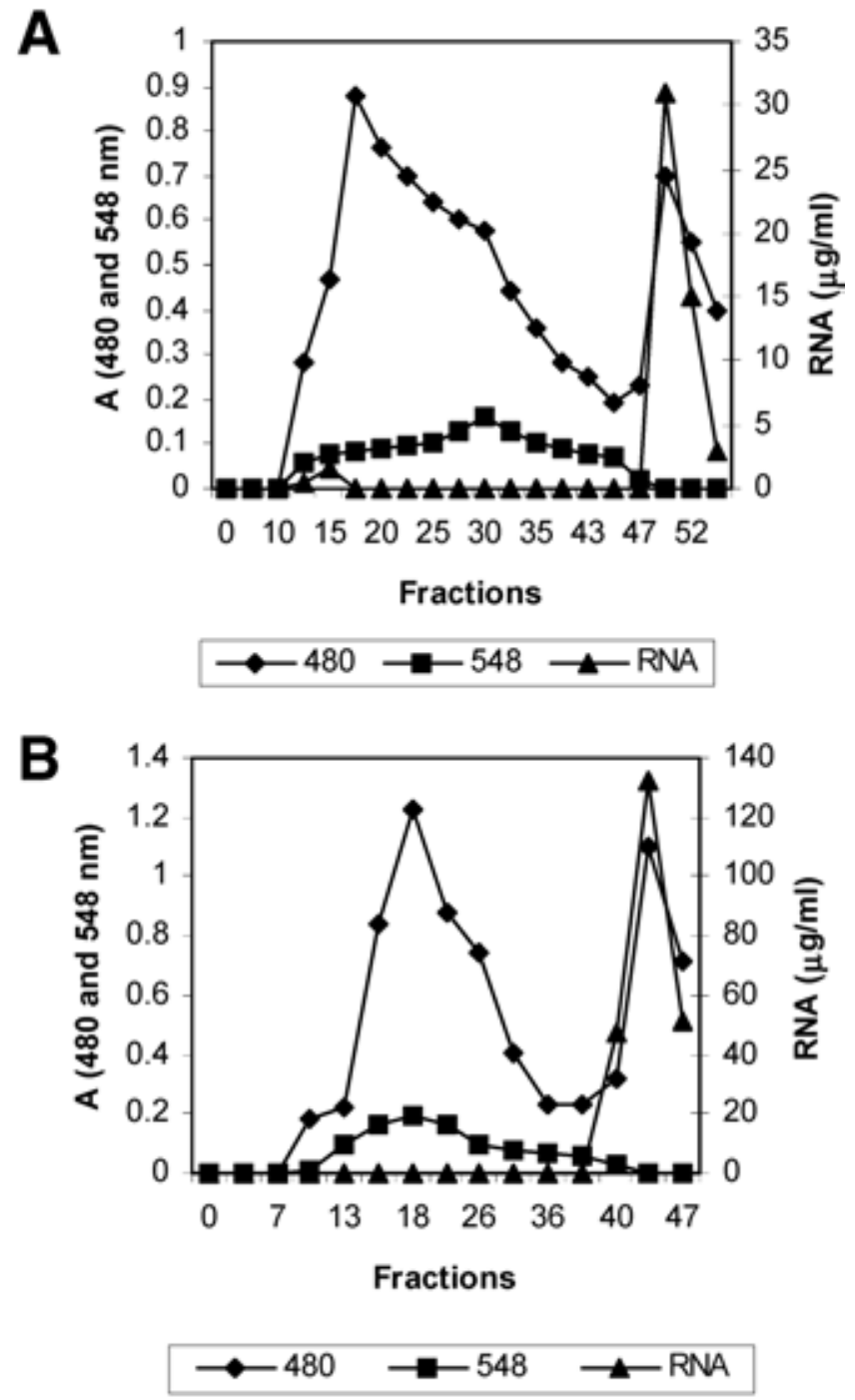

Fig. 7. Fractionation of lipopolysaccharides preparations eluted from a Sepharose 2B column with flow rate of $0.6 \mathrm{ml} \mathrm{min}^{-1}$. The eluate was monitored by assays for carbohydrates, 2-keto-3-deoxyoctonate and nucleic acids recorded at 480, 548, and $260 \mathrm{~nm}$, respectively. A, Elution with $50 \mathrm{mM}$ imidazole at $\mathrm{pH}$ 7.0. Elicitor activity was detected in fractions 15 to 45 , void volume at 18 . B, Elution with $100 \mathrm{mM}$ triethylamine and $10 \mathrm{mM}$ EDTA at $\mathrm{pH}$ 7.0. Elicitor activity was detected in fractions 12 to 36 , void volume at 9 . which was detected by immunogold labeling, and the rapid multiplication of the hrp mutant in mixed inocula, no HR was induced in pepper cv. ECW-30R, which is resistant to wild-type strains expressing AvrBs3. It is clear that the $h r c C$ mutant did not require a functional TTSS in order to gain nutrients required for multiplication. This result argues against a possible role for the type III system in nutrient uptake.

Our search for elicitors of plant cell wall alterations utilized callose as a marker for the response. Electron microscopy showed that eliciting fractions not only induced accumulation of the glucan but also caused alteration to the cell wall such as increased electron density (compare Figs. 1A and 6A). Callose deposition has been considered to reflect local changes to the plant cell membrane, leading to increased $\mathrm{Ca}^{2+}$, which activates membrane-bound callose synthase (Kauss 1987). Cellulose also may be produced by the same enzyme complex (Kudlicka and Brown 1997). Fractionation of bacterial cells led to the identification of LPS as an elicitor of callose and cellulose deposition and also other alterations to the plant cell wall. At certain sites, notably at cell junctions where infiltrated solutions of LPS and other extracts seemed to have concentrated after infiltration (Fig. $6 \mathrm{~A})$, the localized reactions observed were very similar in morphology to those produced by hrp mutant bacteria. We conclude that components of LPS directly induce the plant's localized but complex response.

Carlson and associates (1978) have discussed difficulties in assessing the purity of LPS preparations. They point out that certain criteria of purity, such as symmetry of a peak eluting from a gel filtration column, traditionally have been difficult to obtain for LPS because this macromolecule exists in varying aggregation states. The aggregation of LPS is dependent on its ionic form and the presence of divalent metal ions; therefore, attempts have been made to dissociate the aggregates by chelating agents. Thus, a chromatographic system was developed by Carlson and associates (1978) in which LPS was eluted from the gel filtration column by an EDTA-TEA buffer. Application of this system for purification of our preparation not only rescued the excluded fractions to the included volume of the column but also resulted in a partially symmetrical carbohydrate-KDO-containing peak preceded by KDO-deficient, contaminating carbohydrates. Polyacrylamide gels of the elicitor-active LPS preparations had the ladder-like appearance of degraded LPS as reported by Ojanen and associates (1993) for different $X$. campestris pathovars, the different sizes of LPS bands being attributed to the varying degrees of polymerization of O-chain units.

The ability of LPS from pathovars of $X$. campestris to elicit responses in plant cells has been reported previously (Dow et al. 2000). For example, Meyer and associates (2001) demonstrated that highly purified LPS from $X$. campestris $\mathrm{pv}$. campestris induced a characteristic oxidative burst and enhanced levels of intracellular calcium in cell cultures of Nicotiana tabacum. Both the oxidative burst and calcium influx would be expected to contribute to the localized wall alterations we have found. Dow and associates (Dow et al. 2000; Newman et al. 1997, 2002) have presented evidence that bacterial LPS, in addition to acting as an elicitor per se, may sensitize plants to respond to other elicitors. Working with pepper, they showed that bacterial challenge led to enhanced accumulation of feruloyl tyramine derivatives (FTs) after LPS treatment. Interestingly, the modification of cell walls in onion by the accumulation of FTs has been shown to increase electron density (McLusky et al. 1999), a phenomenon we have associated with papilla deposition. It is possible that the accumulation of FTs contributes to the electron density observed in the plant cell wall in pepper. 
The ability of plants to recognize LPS, which acts either as a direct elicitor or as sensitizer of the plant's response, is a subject of considerable interest. In particular, how the macromolecule reaches the plant cell's perception system, which presumably is cytoplasmic or a component of the plasma membrane, is unclear. Recognition of LPS is considered to be an example of the expression of innate immunity in vertebrate and invertebrate organisms that respond to components of pathogen surface-derived molecules, which are referred to as pathogen-associated molecular patterns (PAMPs) (Nürnberger and Brunner 2002). The perception of LPS in mammals is mediated through Toll-like receptors (TLRs), such as TLR4, that have pattern-recognition capabilities (Miyaka 2004). Whether or not recognition of LPS by plant cells involves similar proteins remains to be confirmed, but other TLRs are known to be involved in the responses of plants to flagellin and certain Avr proteins (Dangl and Jones 2001; Felix et al. 1999). All forms of immunity in plants may be considered innate; therefore, the response to LPS should be considered an expression of basal resistance which must be overcome by any microbe attempting to parasitize plants. Superimposed on this PAMP-mediated basal resistance are the more specific genefor-gene interactions that control varietal resistance.

Wild-type bacteria effectively suppressed reactions to the hrp mutant and also to elicitors including purified LPS. Recognition of PAMPs, which may activate basal or nonhost resistance, represents a potential target for effector proteins delivered through the TTSS. Localized alteration of the plant cell wall probably involves cytoskeletal rearrangement, alteration of ion flux (notably $\mathrm{Ca}^{2+}$ ) across the cell membrane, and a local oxidative burst generating the $\mathrm{H}_{2} \mathrm{O}_{2}$ required for crosslinking within the cell wall. Within animal pathogens, for example in Yersinia enterocolitica, effectors have precisely these targets (Cornelis 2002). Four effectors, YopE, YopH, YopT, and YpkA/YopO, exert a negative effect on cytoskeletal dynamics that suppresses phagocytosis (Rosqvist et al. 1990; Shao et al. 2002). YopH also suppresses the oxidative burst in macrophages (Hakansson et al. 1996; Iriarte and Cornelis 1998). YopP/J inhibits the activation of MAP kinase activity within a cascade of signaling events (Büttner and Bonas 2003; Orth et al. 2000). It seems likely that effectors from plant-pathogenic bacteria that suppress basal defense responses may have similar modes of action. The identity of such effector proteins in $X$. campestris pv. vesicatoria is not known; however, AvrBsT and AvrRxv are two avirulence proteins that have similarity to YopP/J (Orth et al. 2000).

Recent experiments on the function of effectors in plant pathogens have highlighted a role in blocking the HR (Abramovitch et al. 2003; Espinosa et al. 2003; Jackson et al. 1999; Tsiamis et al. 2000). Our experiments with X. campestris pv. vesicatoria indicate that a more general target probably is suppression of PAMP-mediated localized basal resistance reactions, which do not involve the HR or programmed plant cell death.

\section{MATERIALS AND METHODS}

\section{Plants and bacteria.}

Plants of pepper cvs. ECW-10R and ECW-30R, which carry the $B s 1$ and $B s 3$ genes, respectively, for resistance to bacterial spot, were grown to the six- to eight-leaf stage and leaves were inoculated with bacterial suspension by injection as previously described (Minsavage et al 1980). The wild-type strains 71-21 and 85-10 of $X$. campestris pv. vesicatoria, the pathogenic but EPS $^{-}$mutant 85-10::454, and hrp mutant 85-10::hrpA22 were described by Minsavage et al. (1980), Bonas et al. (1991), and Brown et al. (1995). Transconjugants harboring pD36, which contains the coding region of avrBs3 cloned into pDSK602, resulting in overexpression of the AvrBs 3 protein (Brown et al. 1993), were obtained from triparental matings. Bacteria were prepared for inoculation as described by Bonas and associates (1991) and washed three times in $1 \mathrm{mM} \mathrm{MgCl}$ before resuspension at the required concentration. Following injection, plants were maintained at day and night temperatures of 28 and $22^{\circ} \mathrm{C}$, respectively, under a 16 -h photoperiod, with relative humidity not less than $60 \%$. Samples were taken for electron microscopy at various time points from inoculation sites in leaves from two replicate plants. Bacterial multiplication in planta was determined from colony counts prepared from 0.5 $\mathrm{cm}$-diameter leaf discs cut from infiltration sites. Serial dilutions were plated onto King's B medium + rifampicin $(50 \mu \mathrm{g}$ $\left.\mathrm{ml}^{-1}\right)$ with our without kanamycin $\left(20 \mu \mathrm{g} \mathrm{ml}^{-1}\right)$; only the hrp mutant grew on medium supplemented with kanamycin.

\section{Microscopy.}

Leaf tissues were cleared in methanol $(100 \%)$ followed by saturated chloral hydrate, and callose and phenolics located by aniline blue and toluidine blue ( $\mathrm{pH}$ 7.2) staining, respectively (Bestwick et al. 1995; O'Brien and McCully 1981).

Electron microscopy, including immunocytochemistry, was done as described in Brown and associates (1995, 1998). Antibodies used were to AvrBs3 (Knoop et al. 1991) and anti- $\beta, 1-$ 3 glucan (callose) obtained from Genosys Biotechnologies (Europe) Inc. (Cambridge, U.K.). Anti-callose and antiAvrBs3 antibodies were used at 1:1000 and 1:8, respectively. Both primary antibodies were raised in rabbit and were visualized with goat anti-rabbit immunoglobulin G 10- or 30nm gold (Sigma, Poole, U.K.) diluted 1:25. In dual labeling of callose and AvrBs3, callose was labeled first with 30-nm gold, grids were blocked again, and AvrBs3 labeled with 10-nm gold. Negative controls for both antisera involved omission of the primary antibody and incubation in buffer alone. The specificity of the primary antibody for callose was also determined by adsorption of the antiserum with laminarin (250 $\mu \mathrm{g} \mathrm{ml} \mathrm{m}^{-1}$ from Sigma,), which abolished all labeling. Cellulose was located using an exoglucanase-gold enzyme conjugate for labeling $\beta, 1-4$ glucans (Bestwick et al. 1998; Boher et al. 1995). All sections were viewed in a Hitachi H-7000 transmission electron microscope with an accelerating voltage of $75 \mathrm{kV}$.

\section{Preparation of sonicated elicitor.}

A washed bacterial pellet was resuspended in $1 \mathrm{mM} \mathrm{MgCl}_{2}$ to give a concentration of $1 \times 10^{9}$ cells $\mathrm{ml}^{-1}$. Aliquots $(10 \mathrm{ml})$ of cell suspension were transferred to $50-\mathrm{ml}$ sterile test tubes on ice and bacteria disintegrated by sonication for $5 \mathrm{~min}$ (full power using the MSE Soniprep; Sanyo, Leicester, U.K.). The

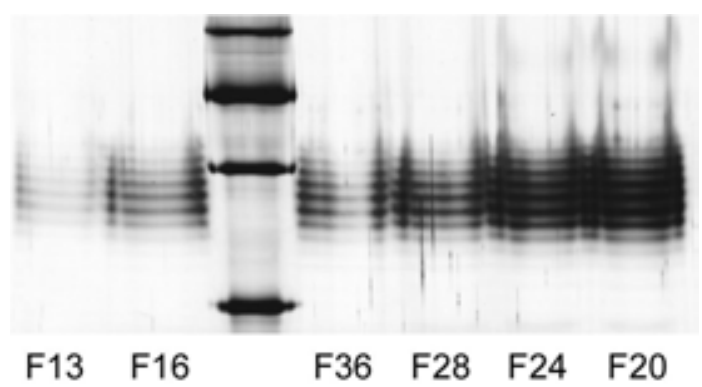

Fig. 8. Silver staining polyacrylamide gel electrophoresis analysis of lipopolysaccharides (LPS) preparations recovered after chromatography on Sepharose 2B eluted with EDTA-triethylamine buffer (100 mM triethylamine and $10 \mathrm{mM}$ EDTA). Elicitor-active fractions (F) all displayed the characteristic banding pattern of LPS. Size markers presented in lane 3 are (from the top) 97, 66, 55, and $36 \mathrm{kDa}$. 
final suspensions were pooled and filter sterilized $(0.2-\mu \mathrm{m}$ pore size; Millipore, Watford, U.K.) to remove unbroken cells and to give a crude sonicated elicitor. Large cell wall fragments were removed by centrifugation at $14,000 \times g$ at $4^{\circ} \mathrm{C}$ for 20 min. The supernatant (termed "soluble elicitor") was transferred to a sterile test tube and the pellet (termed "insoluble elicitor") was resuspended in distilled water to the original volume.

\section{Outer membrane preparations.}

The method was adapted from Hodson and associates (1995). The bacterial pellet, washed twice in a precooled centrifuge, was resuspended in 5 volumes of precooled $1 \%$ (wt/vol) $\mathrm{Na}_{2}$ EDTA $\cdot 2 \mathrm{H}_{2} \mathrm{O}$ adjusted to $\mathrm{pH} 8.0$ with $2 \mathrm{M}$ $\mathrm{NaOH}$. After incubation on ice at $0^{\circ} \mathrm{C}$ for $1 \mathrm{~h}$, the suspension was centrifuged at $40,000 \times g$ for $20 \mathrm{~min}$ at $0^{\circ} \mathrm{C}$ and the supernatant was filter-sterilized $(0.2-\mu \mathrm{m}$ pore $)$. EDTA was removed by passage of the solution down a desalting column (10 DG columns; Bio-Rad, Hemel Hempstead, U.K.) eluted with distilled water. The desalted extract was then concentrated using a 6-kDa cut-off Centricon membrane (Millipore). Alternatively, outer membranes were recovered by ultracentrifugation of the EDTA extract at $100,000 \times g$ for 18 $\mathrm{h}$ at $4^{\circ} \mathrm{C}$. The pellet was washed with distilled water three times before final resuspension in distilled water. All fractions were stored at $-20^{\circ} \mathrm{C}$.

LPS was extracted and fractionated from EDTA extracts with aqueous hot phenol solution. A 3-ml aliquot of the EDTA extract was mixed with $3 \mathrm{ml}$ of phenol-water $(90 \% \mathrm{wt} / \mathrm{vol})$ preheated to $65^{\circ} \mathrm{C}$ and the mixture was heated to 65 to $70^{\circ} \mathrm{C}$ for $15 \mathrm{~min}$ in a water bath with vigorous shaking. After cooling in an ice bath, the mixture was centrifuged at $12,000 \times g$ $\left(20 \mathrm{~min}\right.$ at $4^{\circ} \mathrm{C}$ ), which resulted in the formation of three layers, a water layer, a phenol layer, and a thin, insoluble residue at the phenol-water interface. The water phase was removed by pipette, an equal volume of distilled water was added to the phenol phase and insoluble residue, and the heat treatment, cooling, and centrifugation were repeated. The two water and phenol phases were combined and dialyzed separately against deionized distilled water for 3 days with at least 10 changes of water. The dialyzed preparations then were inoculated into leaves.

\section{Treatment of elicitor preparations.}

Soluble elicitors were fractionated based on MW by centrifugation at $1,000 \times \mathrm{g}\left(4^{\circ} \mathrm{C}, 30 \mathrm{~min}\right)$ over a 100 -kDa cut-off ultramembrane (Centricon), and the activity of fractions above and below $100 \mathrm{kDa}$ was assayed.

Heat sensitivity was determined by incubation at $100^{\circ} \mathrm{C}$ for $10 \mathrm{~min}$ or autoclaving for $10 \mathrm{~min}$ at $1 \mathrm{~kg} \mathrm{~cm}^{-2}$. Preparations were also subjected to two cycles of freezing $\left(-20^{\circ} \mathrm{C}\right)$ and thawing (at room temperature) before inoculation into leaves. The soluble elicitor and EDTA extract were also treated with different proteases (all obtained from Sigma). Solutions of elicitors were treated with pronase, trypsin, or proteinase $\mathrm{K}$ at $0.2 \mathrm{mg} \mathrm{ml}^{-1}$. The samples were incubated at $37^{\circ} \mathrm{C}$ for $4 \mathrm{~h}$. To inactivate the proteases, the solutions were heated at $100^{\circ} \mathrm{C}$ for $10 \mathrm{~min}$ and, after cooling to room temperature, inoculated into leaves. As controls, the enzymes were incubated in $50 \mathrm{mM}$ Tris buffer at $\mathrm{pH} 7.5$ instead of the elicitor solution.

\section{Large-scale preparation of LPS.}

For each extraction, 5 liters of 85-10::hrpA22 bacterial cell suspensions grown overnight in King's B medium were used; and pelleted cells were dried with acetone. The dried pellet then was ground finely using a pestle and mortar in a fume cupboard. The ground acetone-dried cells were resuspended in deionized distilled water with stirring ( $1 \mathrm{~g}: 17.5 \mathrm{ml}$ of water).
The aqueous hot phenol method as described above (Westphal and Jann 1965) was used to extract LPS on a preparative scale. After separation of phases and exhaustive dialysis, preparations were ultracentrifuged separately at $104,000 \times g\left(4^{\circ} \mathrm{C}, 3.5\right.$ h) and the pellets were resuspended in deionized distilled water with the aid of a hypodermic syringe and wide-bore needle. RNase $\left(0.1 \mathrm{mg} \mathrm{ml}^{-1}\right.$, Sigma) was added and left at $4^{\circ} \mathrm{C}$ overnight. DNase $\left(0.1 \mathrm{mg} \mathrm{ml}^{-1}\right.$, Sigma) then was added and incubated at $37^{\circ} \mathrm{C}$ for $2 \mathrm{~h}$, followed by the addition of proteinase $\mathrm{K}$ $\left(0.1 \mathrm{mg} \mathrm{ml}^{-1}\right)$ and incubation at $37^{\circ} \mathrm{C}$ for $2 \mathrm{~h}$. The ultracentrifugation step was repeated and the pellets were resuspended in deionized distilled water.

LPS preparations recovered after successive RNase, DNase, and proteinase $\mathrm{K}$ treatments and repeated ultracentrifugation were further fractionated with a $1.5-$ by $-42-\mathrm{cm}$ gel filtration chromatographic column filled with the Sepharose-2B matrix (Pharmacia, Amersham, U.K.). The column was equilibrated and eluted with either $50 \mathrm{mM}$ imidazole, $\mathrm{pH} 7.0$, or with 100 $\mathrm{mM}$ TEA and $10 \mathrm{mM}$ EDTA neutralized to $\mathrm{pH} 7.0$ with $\mathrm{HCl}$ (Carlson et al. 1978). The crude LPS preparations were resuspended in $5 \mathrm{ml}$ of the same buffer prior to application to each column. Fractions $(6-\mathrm{ml})$ were collected at a flow rate of 0.6

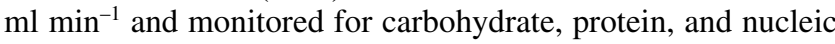
acids. All fractions were desalted either by dialysis against deionized distilled water or using desalting columns. The desalted fractions were bioassayed and also analyzed by sodium dodecyl sulfate PAGE as described by Ojanen and associates (1993).

\section{KDO, protein, carbohydrate, and nucleic acid determinations.}

The thiobarbituric acid assay of Osborn (1963) was used for the estimation of KDO after hydrolysis of LPS-containing preparations in $1 \mathrm{M} \mathrm{HC} 1$ at $100^{\circ} \mathrm{C}$ for $2 \mathrm{~h}$ or in $0.1 \mathrm{M}$ sodium acetate $(\mathrm{pH} 4.4)$ at $100^{\circ} \mathrm{C}$ for $1 \mathrm{~h}$. LPS was estimated based on Ojanen and associates (1993), who determined that $1 \mathrm{mg}$ of hydrolyzed LPS from $X$. campestris pv. vesicatoria contained $0.1 \mu \mathrm{mol}$ KDO (i.e., 18.8 or $24.7 \mu \mathrm{g}$ KDO $\equiv 1 \mathrm{mg}$ of LPS, with or without prior hydrolysis, respectively). Carbohydrates were determined by the phenol-sulphuric acid assay according to Dubois and associates (1956). A DNA/RNA calculator (Pharmacia) set at $260 \mathrm{~nm}$ was used to estimate nucleic acid content of preparations, recorded as $\mu \mathrm{g}$ of RNA $\mathrm{ml}^{-1}$.

\section{ACKNOWLEDGMENTS}

We wish to thank the Agricultural Research, Education and Extension Organization (AREEO) of the Islamic Republic of Iran for financial support for M. Keshavarzi, and T. Smith and M. Dow for initiation into the world of LPS.

\section{LITERATURE CITED}

Abramovitch, R. B., Kim, Y. J., Chen, S., Dickman, M. B., and Martin, G. B. 2003 Pseudomonas type III effector AvrPtoB induces plant disease susceptibility by inhibition of host programmed cell death. EMBO (Eur. Mol. Biol. Organ.) J. 22:60-69.

Bestwick, C. S., Bennett, M. H., and Mansfield, J. W. 1995. Hrp mutant of Pseudomonas syringae pv. phaseolicola induces cell wall alterations but not membrane damage leading to the HR in lettuce (Lactuca sativa). Plant Physiol. 108:503-516.

Bestwick, C. S., Brown, I. R., Mansfield, J. W., Boher, B., Nicole, M., and Essenberg, M. 1998. Host reactions-plants. Methods Microbiol. 27:539-572.

Boher, B., Kpémoua, K., Nicole, M., Luisetti, J., and Geiger, J. P. 1995. Ultrastructure of interactions between cassava, and Xanthomonas campestris pv. manihotis: cytochemistry of cellulose, and pectin degradation in a susceptible cultivar. Phytopathology 85:777-788.

Bonas, U., Schulte, R., Fenselau, S., Minsavage, G. V., Staskawicz, B. J. and Stall, R. E. 1991. Isolation of a gene cluster from Xanthomonas 
campestris pv. vesicatoria that determines pathogenicity and the hypersensitive response on pepper and tomato. Mol. Plant-Microbe Interact. 4:81-88.

Brentwood, B., and Cronshaw, J. 1978. Cytochemical localization of adenosine triphosphatase in the phloem of Pisum sativum and its relation to the function of transfer cells Planta 140:111-120.

Brown I., Trethowan, J., Kerry M., Mansfield J. W., and Bolwell, G. 1998. Localization of components of the oxidative cross-linking of glycoproteins and of callose synthesis in papillae formed during the interaction between non-pathogenic strains of Xanthomonas campestris and French bean mesophyll cells. Plant J. 15:333-343.

Brown, I. R., Mansfield, J. W., and Bonas, U. 1995. hrp genes in Xanthomonas campestris pv. vesicatoria determine ability to suppress papilla deposition in pepper mesophyll cells. Mol. Plant-Microbe Interact. 8:825-836.

Brown, I. R., Mansfield, J. W., Irlam, I., Conrads-Strauch, J., and Bonas, U. 1993. Ultrastructure of interactions between Xanthomonas campestris pv. vesicatoria and pepper, including immunocytochemical localization of extracellular polysaccharides and the AvrBs3 protein. Mol. Plant-Microbe Interact. 6:376-386.

Büttner, D., and Bonas, U. 2003. Common infection strategies of plant and animal pathogenic bacteria. Curr. Opin. Plant Biol. 6:312-319.

Carlson, R. W., Sanders, R., Napoli, C., and Albersheim, P. 1978. Hostsymbiont interactions III. Purification and partial characterization of Rhizobium lipopolysaccharide. Plant Physiol. 62:912-917.

Cornelis, G. R. 2002. The Yersinia Ysc-Yop "type III" weaponry. Nat. Rev. Mol. Cell Biol. 2002:742-752.

Cornelis, G. R., and Van Gijsegem, F. 2000. Assembly and function of type III secretory systems. Annu. Rev. Microbiol. 54:735-774.

Dangl, J. L., and Jones, J. G. D. 2001. Plant pathogens and integrated responses to infection. Nature 411:826-833.

de Torres, M., Sanchez, P., Fernandez-Delmond, I., and Grant, M. 2003. Expression profiling of the host response to bacterial infection: the transition from basal to induced defense responses in RPM1-mediated resistance. Plant J. 33:665-676.

Dow, M., Newman, M.-A., and von Roepenack, E. 2000 The induction and modulation of plant defense responses by bacterial lipopolysaccharides. Annu. Rev. Phytopathol. 38:241-261.

Dubois, M., Hamilton, K. A., Rebers, J. K., and Smith, P. A. 1956. Colorimetric method for determination of sugars and related substances. Anal. Chem. 28:350-356.

Espinosa, A., Guo, M., Tam, V. C, Fu, Z. Q, and Alfano, J. R. 2003. The Pseudomonas syringae type III-secreted protein HopPtoD2 possesses protein tyrosine phosphatase activity and suppresses programmed cell death in plants. Mol. Microbiol. 49:377-387.

Felix, G., Duran, J. D., Volko, S., and Boller, T. 1999. Plants have a sensitive perception system for the most conserved domain of bacterial flagellin. Plant J. 18:265-276.

Hakansson, S., Galyov, E. E., Rosqvist, R., and Wolf-Watz, H. 1996 The Yersinia YpkA Ser/Thr kinase is translocated and subsequently targeted to the inner surface of the HeLa cell plasma membrane. Mol. Microbiol. 20:593-603.

Hauck, P., Thilmony, R., and He, S. Y. 2003. A Pseudomonas syringae type III effector suppresses cell wall-based extracellular defense in susceptible Arabidopsis plants. Proc. Natl. Acad. Sci. U.S.A. 8:8577-8582.

Heath, M. C. 2000. Nonhost resistance and non-specific plant defenses. Curr. Opin. Plant Biol. 3:315-319.

Innes, R. W. 2001. Targeting the targets of Type III effector proteins secreted by phytopathogenic bacteria. Mol. Plant Pathol. 2:109-113.

Hodson, A., Smith., A., and Hignett, R. 1995. Characterization of an outer membrane preparation of Pseudomonas syringae pv. mors-prunorum and its biological activities in planta. Physiol. Mol. Plant Pathol. 47:159-172.

Iriarte, M., and Cornelis, G. R. 1998. YopT, a new Yersinia Yop effector protein, affects the cytoskeleton of the host cells. Mol. Microbiol. 29:915-929.

Jackson, J. W., Athanassopoulos, E., Tsiamis, G., Mansfield, J. W., Sesma, A., Arnold, D. L., Gibbon, M. J., Murillo, J., Taylor, J. D., and Vivian, A. 1999. Identification of a pathogenicity island, which contains genes for virulence and avirulence, on a large native plasmid in the bean pathogen Pseudomonas syringae pathovar phaseolicola. Proc. Natl. Acad. Sci. U.S.A. 96:10875-10880.

Jakobek, J. L., and Lindgren, P. B. 1993. Generalized induction of defense responses in bean is not correlated with the induction of the hypersensitive reaction. Plant Cell 5:49-56.

Kauss, H. 1987. Some aspects of calcium-dependent regulation in plant metabolism. Annu. Rev. Plant Physiol. 38:48-72.

Knoop V., Staskawicz B. J., and Bonas, U. 1991. Expression of the avirulence gene avrBs 3 from Xanthomonas campestris pv. vesicatoria is not under the control of hrp genes and is independent of plant factors. J. Bacteriol. 174:7142-7150.

Kudlicka, K., and Brown R. M. 1997. Cellulose and callose biosynthesis in higher plants. 1. Solubilization and separation of $(1 \rightarrow 3)$ and $(1 \rightarrow 4) \beta$ glucan synthase activities from mung bean. Plant Physiol. 115:643-656.

Lindgren, P. 1997. The role of hrp genes during plant-bacterial interactions. Annu. Rev. Phytopathol. 35:129-152.

McLusky, S. R., Bennett, M. H., Beale, M., Lewis, M. J., Gaskin, P., and Mansfield, J. W. 1999. Cell wall alterations and localized accumulation of feruloyl-3'-methoxytyramine in onion epidermis at sites of attempted penetration by Botrytis allii are associated with actin polarization, peroxidase activity and suppression of flavonoid biosynthesis. Plant J. 17:523-534.

Mellersh, D. G., Founds, I. V., Higgins, V. J., and Heath, M. C. 2002. $\mathrm{H}_{2} \mathrm{O}_{2}$ plays different roles in determining penetration failure in three diverse plant-fungal interactions. Plant J. 29:257-268.

Meyer, A., Puhler, A., and Karsten, N. 2001. The lipopolysaccharides of the phytopathogen Xanthomonas campestris pv. campestris induce an oxidative burst reaction in cell cultures of Nicotiana tabacum. Planta 213:214-222.

Minsavage, G. V., Dahlbeck, D., Whalen, M. C., Kearney, B., Bonas, U., Staskawicz, B. J., and Stall, R. E. 1980. Gene-for-gene relationships specifying disease resistance in Xanthomonas campestris pv. vesicatoria-pepper interactions. Mol. Plant-Microbe Interact. 3:41-47.

Miyake, K. 2004. Innate recognition of lipopolysaccharide by toll-like receptor 4-MD-2. Trends Microbiol. 12:186-192.

Newman, M.-A., Daniels, M. J., and Dow, J. M. 1997. The activity of lipidA and core components of bacterial lipopolysaccharides in the prevention of the hypersensitive response in pepper. Mol. PlantMicrobe Interact. 10:926-928.

Newman, M.-A., von Roepenack-Lahaye, E., Parr, A., Daniels, M. J., and Dow, M. J. 2002. Prior exposure to lipopolysaccharide potentiates expression of plant defenses in response to bacteria. Plant J. 29: 487-495.

Nürnberger, T., and Brunner, F. 2002. Innate immunity in plants and animals: emerging parallels between recognition of general elicitors and pathogen-associated molecular patterns. Curr. Opin. Plant Biol. $5(4): 318-324$.

O'Brien, T. P., and McCully, M. E. 1981. The Study of Plant Structure: Principles and Selected Methods. Termarcarphi Pty Ltd., Melbourne, Australia.

O’Connell, R. J., Brown, I. R., Mansfield, J. W., Bailey, J. A., Mazau, D., Rumeau, D., and Esquerré-Tugayé, M. T. 1990. Immunocytochemical localization of hydroxyproline-rich glycoproteins accumulating in melon and bean at sites of resistance to bacteria and fungi. Mol. PlantMicrobe Interact. 2:33-40.

Ojanen, T., Helander, I. M., Haahtela, K., Korhonen, T. K., and Laakso, T. 1993. Outer membrane proteins and lipopolysaccharides in pathovars of Xanthomonas campestris. Appl. Environ. Microbiol. 59:4143-4151.

Orth, K., Xu, Z., Mudgett, M. B., Bao, Z. Q., Palmer, L. E., Bliska, J. B., Mangel, W. F., Staskawicz, B., and Dixon, J. E. 2000. Disruption of signaling by Yersinia effector YopJ, a Ubiquitin-like protein protease. Science 290:1594-1597.

Osborn, M. J. 1963. Studies on the gram negative cell wall. I. Evidence for the role of 2-keto-3-deoxyoctonate in the lipopolysaccharide of Salmonella typhimurium. Proc. Natl. Acad. Sci. U.S.A. 50:499-506.

Pate, J. S., and Gunning, B. E. S. 1972. Transfer cells. Annu. Rev. Plant Physiol. 23:135-156.

Rosqvist, R., Forsberg, A., Rimpilainen, M., Bergman, T., and Wolf-Watz, H. 1990. The cytotoxic protein YopE of Yersinia obstructs the primary host defense. Mol. Microbiol. 4:657-667.

Shao, F., Merritt, P. M., Bao, Z., Innes, R. W., and Dixon, J. E. 2002. A Yersinia effector and a Pseudomonas avirulence protein define a family of cysteine proteases functioning in bacterial pathogenesis. Cell 109:575-588.

Tsiamis, G., Mansfield, J. W., Hockenhull, R., Jackson, R. W., Sesma, A., Athanassopoulos, E., Bennett, M., Stevens, C. Vivian, A., Taylor, J. D., and Murillo, J. 2000. Cultivar-specific avirulence and virulence functions assigned to avrPphF in Pseudomonas syringae pv. phaseolicola, the cause of bean halo-blight disease. EMBO (Eur. Mol. Biol. Organ.) J. 13:3204-3214.

Westphal, O., and Jann, K. 1965. Bacterial lipopolysaccharide. Extraction with phenol-water and further application of the procedure. Methods Carbohydr. Chem. 5:83-91. 
Erratum, Vol. 17, No. 7, 2004

A manuscript by Keshavarzi et al. (7:805-815) entitled "Basal Defenses Induced in Pepper by Lipopolysaccharides Are Suppressed by Xanthomonas campestris pv. vesicatoria" contained errors in Table 3. The corrected table appears below.

Table 3. Activities of sonicated suspension and soluble elicitors prepared from Xanthomonas campestris pv. vesicatoria strain 85-10::hrpA22 standardized to the initial concentration of suspension, $10^{9}$ bacteria $\mathrm{ml}^{-1}$

\begin{tabular}{ll}
\hline Elicitor & End point $^{\mathrm{a}}$ \\
\hline Sonicated suspension $^{\mathrm{b}}$ & $1 / 64$ \\
$\quad$ Soluble elicitor & $1 / 64$ \\
Insoluble elicitor & $1 / 32$ \\
Soluble elicitor & \\
$>100 \mathrm{kDa}$ & $1 / 64$ \\
$<100 \mathrm{kDa}$ & $\ldots$ \\
Soluble elicitor, heat treated & $1 / 64$ \\
Supernatant & $1 / 64$ \\
Pellet & $1 / 16$ \\
$>100 \mathrm{kDa}$ & $1 / 64$ \\
$<100 \mathrm{kDa}$ & $\ldots$ \\
Soluble elicitor, freeze-thawed & $1 / 64$ \\
$>100 \mathrm{kDa}$ & $1 / 64$ \\
$<100 \mathrm{kDa}$ & $\ldots$ \\
\hline Soluble elicitor treated with proteases & $1 / 32$ or $1 / 64$ \\
\hline
\end{tabular}

${ }^{a}$ End point of activity was determined by injection of doubling dilutions of elicitor preparations into leaf tissues; .... indicates no activity before dilution. Concentrations were adjusted to correspond to the original volume of bacterial suspension at $10^{9}$ cells $\mathrm{ml}^{-1}$. Data are summarized from repeated experiments.

${ }^{\mathrm{b}}$ Boiled suspension gave the same end point. 